\title{
Resenhas
}

\section{Contribuições para identidade profissional do Psicólogo Escolar}

\section{Contributions to professional identity of the School Psychologist}

\author{
Marinho-Araújo, C. M. \& Almeida, S. F. C. de (2005). Psicologia Escolar: Construção e \\ Consolidação da Identidade Profissional. \\ Campinas-SP: Editora Alínea, 121 p.
}

O livro "Psicologia Escolar: construção e consolidação da identidade profissional", escrito pelas professoras doutoras Claisy Maria MarinhoAraújo e Sandra Francesca Conte de Almeida, apresenta uma possibilidade diferenciada de atuação em Psicologia Escolar.

A Psicologia Escolar é um campo de produção científica e de atuação profissional que se caracteriza pela inserção da Psicologia na escola, com o objetivo precípuo de promover o processo educativo. Contudo, por muito tempo, as discussões acerca da relação entre a Psicologia e a Educação, centraram-se em críticas às ações dos psicólogos escolares em relação às demandas e problemas da escola. Essas discussões têm tido muitos reflexos, entre os quais se destacam os questionamentos e críticas quanto à formação dos psicólogos escolares.

Apesar de diversas produções apontarem para a necessidade de se repensar a atuação e a formação em Psicologia, em virtude da natureza das questões que permeiam o contexto escolar, faltava à área um referencial que indicasse uma intervenção diferente daquela que, até então, era criticada.
Dessa forma, ancorando-se na necessidade de contribuir para a formação e a prática profissional daqueles que se comprometem com a qualidade dos processos que permeiam a ação educativa, o livro em análise apresenta-se como um importante referencial à Psicologia Escolar.

Para a elaboração desta obra as autoras empenharam-se em articular as contribuições teóricas da Psicologia Escolar com as questões relacionadas à formação, atuação e identidade do profissional desta área. Ao final, conseguem apresentar uma proposta de intervenção que, ao mesmo tempo, transforma a realidade social e marca a construção da identidade profissional dos psicólogos escolares.

O livro "Psicologia Escolar: construção e consolidação da identidade profissional” está organizado em três grandes partes. A primeira delas - "Psicologia Escolar: história e conexões, fio e desafios" - se dedica a apresentar a relação histórica que se construiu entre a Psicologia e a Educação, e é composta por três capítulos. O capítulo um - "Encontros, Desafios e Impasses: a 
história da articulação entre a Psicologia e a Educação no Brasil" - trata da constituição da Psicologia enquanto ciência e do seu processo de aproximação com a Educação, apontando a especificidade da Psicologia Escolar enquanto área de atuação que tem um compromisso teóricoprático para com as questões escolares. O capítulo dois - "Delimitando Espaços, Estabelecendo Conexões: educação e escola" - discorre sobre a educação enquanto fenômeno social e o papel específico da escola diante da formação humana. $\mathrm{O}$ capítulo três - "Professor e Escola: trabalho e profissão" - se destina a apontar fatores envolvidos na formação e desempenho dos professores, sinalizando para o sofrimento psíquico vivenciado pelos docentes em decorrência das condições específicas do trabalho que desenvolvem.

A segunda parte do livro - "Psicologia Escolar: identidade em construção" - faz um resgate histórico da Psicologia Escolar e embasa a discussão de questões relacionadas à formação e identidade do psicólogo escolar. O capítulo quatro "Memória e Atualidade" - retoma de forma mais aprofundada a conexão entre a Psicologia e a Educação, apontando para a consolidação da Psicologia Escolar enquanto um campo de articulação entre o conhecimento psicológico e a educação. O capítulo cinco - "Formação como Ação Formativa" - pauta-se em pesquisas desenvolvidas sobre a formação dos psicólogos escolares para sinalizar que, tanto a formação inicial deste profissional quanto a continuada, devem se basear nas especificidades que a atuação na escola exige.

A terceira e última parte do livro - "Psicologia Escolar e a Atuação profissional" - traz, num único capítulo, uma proposta de atuação em Psicologia Escolar, fundamentada em uma perspectiva institucional e preventiva, de forma que o capítulo seis - "Intervenção Institucional: possibilidades de prevenção em Psicologia Escolar" - apresenta um modelo de atuação que se sustenta sobre quatro dimensões intrinsecamente relacionadas, quais sejam: o mapeamento institucional, o espaço de escuta psicológica, a assessoria ao trabalho coletivo e o acompanhamento ao processo de ensinoaprendizagem. Ao delinear as atividades e procedimentos que podem ser contemplados em cada uma das quatro dimensões, as autoras posicionam-se diante do compromisso de contribuir para a consolidação de uma identidade profissional coadunada com as demandas e necessidades de um contexto marcadamente contraditório e em constante transformação.

A proposta de intervenção para a atuação em Psicologia Escolar apresentada nesta obra aponta para o fato de que o ritmo das transformações que permeiam as práticas profissionais exige, do psicólogo escolar, um constante pensar e refletir, como subsídio imprescindível à consolidação de sua identidade profissional.

Diante de tantas contribuições, entende-se que o livro "Psicologia Escolar: construção e consolidação da identidade profissional" assumiu uma responsabilidade social e ética frente ao desafio de capacitar o psicólogo que atua no contexto escolar, colaborando para o seu desenvolvimento profissional por meio de uma proposta de atuação preventiva em Psicologia Escolar, baseada em uma perspectiva institucional. Àqueles que se dedicam a promover a articulação entre Psicologia e Educação, recomenda-se, sem 
dúvida, esta obra como uma rica oportunidade de se apropriar de novas formas de intervenção psicológica no contexto escolar.
Cynthia Bisinoto Evangelista de Oliveira Psicóloga Escolar

Mestre em Psicologia e Doutoranda do Programa de Processos de Desenvolvimento Humano e Saúde da Universidade de Brasília 